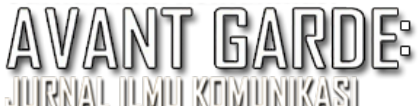

\title{
Identitas Visual Milenial Dalam Merek Minuman Bubble Tea di Tangerang Selatan
}

\author{
Arief Ruslan \\ Arief.ruslan@budiluhur.ac.id \\ Universitas Budi Luhur, Jl. Ciledug Raya, Petukangan Utara, Jakarta Selatan, 12260
}

Submitted: 18 Maret 2020 Revised: 1 April 2020 Accepted: 13 Mei 2020

\begin{abstract}
Abstrak
Artikel ini menyelidiki identitas visual yang dilakukan pebisnis minuman ringan masa kini yang menargetkan para masyarakat milenial di wilayah Tanggerang Selatan. Minuman kekinian, populer sebagai minuman generasi milenial dan membuat bisnis ini menjamur serta saling berkompetisi. Dengan menarik dari beberapa bentuk identitas visual dari dalam "branding" oleh para pebisnis, wacana identitas milenial secara tidak langsung dibangun atas beberapa prinsip-prinsip visual. Identitas visual menjadi saluran utama sebagai alat komunikasi dan menentukan jati diri sebagai identitas sosial. Penelitian ini berfokus kepada para pebisnis minuman ringan "bubble drink", atau sering kali disebut boba drink, yang membangun identitas mereka dengan logo sebagai identitas milenial. Menggunakan metode kualitatif dengan observasi dan studi literatur, penelitian ini mengambil identitas visual (logo) 17 pebisnis minuman boba drink di wilayah Tangerang Selatan. Dengan logo tersebut, peneliti mengidentifikasikan konsep komunikasi dalam bentuk visual, yang selanjutnya membongkar tanda-tanda yang hadir dalam elemen metaphore visual, yaitu bentuk, warna, dan tipografi. Temuan dalam penelitian ini adalah a) Tatanan visual yang dihadirkan oleh para pebisnis dalam membangun identitas anak milenial dipresentasikan dengan "shapes" luwes, warna-warna dominan kontras, dan mengunggulkan peranan kata yang dikombinasikan oleh bentuk tipografi; b) gaya visual yang dibangun bukan hanya sebagai kesederhanaan bentuk, selain itu juga sebagai identitas masyarakat kekinian.
\end{abstract}

Kata kunci: brand, bubble drink, identitas milenial, identitas visual.

\section{MILENNIAL VISUAL IDENTITY IN SOFT DRINKS “TEA BUBBLE” BRAND IN SOUTH TANGERANG}

\begin{abstract}
This article investigates the visual identity of "newest" soft drink businesses that target milennial communities in the South Tangerang region. The "kekinian" drinks, popular as millennial drinks and make this business blooming and compete with one another. Appending from some form of visual identity from within "branding" by business man, the discourse on milennial identity is indirectly built on several visual principles. Visual identity becomes the main channel as a communication tool and determines identity as social identity. This research focuses on "bubble drink" soft drink business people, or often called bobba drinks, who build their identity with logos as milennial identity. Using a qualitative method with observation and study of literature, this study took the visual identity (logoS) of 17 boba drink businesses in the South Tangerang area. With this logo, the researcher identifies the concept of communication in a visual form, which then unravels the signs that are present in the visual metaphore element, namely shape, color, and typography. The findings in this study are, a) The visual order presented by business people in building milennial children's identity is presented with flexible shapes, dominant colors that are contrast, and promotes the role of words combined with typographic forms. b) visual style that is built not only as a form of simplicity, but also as the identity "kekinian" society.
\end{abstract}

Keywords: brand, bubble drink, milenial identity, visual identity 


\section{PENDAHULUAN}

Boba adalah minuman yang sedang naik daun untuk para pencinta kuliner di ibukota. Tren minuman boba (bubble) nampaknya menjadi pilihan gaya minuman kekinian untuk anak milenial dan semakin menjamur. Hal itu terlihat dari banyaknya gerai-gerai minuman asal Taiwan tersebut hadir di tengah masyarakat. Teh Taiwan dijual dalam jumlah besar ke pasar luar negeri yang merupakan pokok utama dalam perekonomian ekonomi sebagai komoditas perdagangan internasional (Frojdo, 2018; Chang, 2017). Dilansir pada Kumparan.com bahwa minuman bubble punya kekuatan inovasi yang besar. Minuman ini terus bertransformasi dan menciptakan daya tarik. Rasa baru terus bermunculan, tampilannya pun kian beragam, yang menjadi tren sejak awal 90-an, rupanya butuh waktu sepuluh tahun untuk membawa minuman bubble masuk ke Indonesia. Tak mengherankan bila sebuah artikel dalam Business Today memprediksi pertumbuhan tahunan pasar bubble tea dari 2017-2023 naik hingga 7,3 persen

(https://kumparan.com/kumparanfood/cerita -boba-bubble-drink-yang-digandrungi-anakmuda-1rPinRkuKoA Diakses 10 Maret 2020 jam 20:05 WIB).

Minuman trendi ini menjangkiti setiap jalanan Tangerang Selatan. Geraigerai berlimpangan dengan bermacammacam bentuk dan gaya. Identitas visual (logo) pada gerai ini pun membangun identitas merek produk tersebut. Penelitian yang dilakukan oleh Black dan Veloutsou (2016) menyajikan data dengan menyoroti cara kerja developing brands konsumen menggunakan kota asal mereka, sejarah kehidupan, dan pekerjaan untuk membangun merek identitas komunitas dan konsumen secara pribadi, dengan melihat pergerakan sumber merek sebagai simbolisitas mereka.

Nilai utama yang melekat pada logo secara tradisional berfokus pada identifikasi dan diferensiasi merek dari pesaingnya (MacInnis et al., 1999). Namun, penelitian tentang logo yang lain pun telah menyoroti keluaran konsumen turunan lainnya seperti identitas dan afektif konsumen, menekankan bahwa logo dapat menghasilkan emosi positif, serta menyampaikan makna dan identitas konsumen (Van der Lans et al. , 2009). Lutz dan Lutz (1977) adalah yang pertama menghadirkan logo sebagai identitas gaya masyarakat serta sebagai pemicu reaksi afektif.

Meskipun makna merek dan logo sering membingungkan dan kadang-kadang merujuk pada hal yang sama, tetapi idetifikasi dan kategori menjadi bagian yang dapat membedakan antara kedua bentuk tersebut (Ashworth \& Kavaratzis, 2009). The American Marketing Association (2018) mendefinisikan merek sebagai nama, istilah, desain/rancangan, simbol, atau fitur lainnya yang mengidentifikasi barang atau jasa satu penjual sebagai pembeda dari penjual lain. Selain identitas dan diferensiasi, Kotler dan Keller (2016) menyatakan bahwa merek juga merupakan jaringan asosiasi dalam pikiran perancang dan para pengusaha yang terdiri dari pengetahuan merek, citra merek, kesadaran, dan sikap merek. Aaker (2007) 
memberikan definisi yang serupa dan menunjuk ke empat dimensi utama yang membentuk kuat merek yaitu kesadaran, asosiasi, persepsi kualitas dan loyalitas merek.

Pittard, Ewing, dan Jevons (2007), mendefinisikan dan mengartikan logo sebagai bentuk elemen grafis dan jenis huruf mulai dari yang dibentuk dan tersusun oleh kata, logotip dan serta gambar-gambar yang sederhana. Persepsi terhadap visual mempunyai peranan penting untuk memberikan citra serta 'image' kelompok dan komunitas (Keller, 2003). Seringkali ketika ditanya tentang partikular merek, konsumen lebih mudah untuk mengidentifikasi melalui logonya, yang berfungsi sebagai identitas visual untuk mengambil informasi terhadap merek yang diartikan atau mungkin dimaknai oleh mereka (De Chernatony dan Dall'Olmo Riley, 1998).

Tujuan dalam penelitian ini adalah mendeskripsikan terhadap nilai perusahaan yang ditunjukan dengan logonya (Jenkins, 2003), dan mendeskripsikan, mengungkapkan bagaimana nama, logo, dan slogan yang menjadi fitur penting dari merek, dan ini telah lama diakui sebagai alat yang sangat berpotensial dalam menarik pengunjung, bahkan logo menjadikan identitas kepada pengunjung tersebut (Sinclair Maragh ,2018).

Sebagai tanda identitas merek, logo dapat merujuk ke berbagai elemen grafis atau jenis huruf, mulai dari kata yang tergabung tanda, yaitu termasuk tanda kata atau tanda huruf bergaya, hingga berbasis gambar, yaitu termasuk tanda bergambar
(Henderson dan Cote, 1998; Wheeler, 2003). Elemen visual memberikan peranan yang sangat penting sebagai esensi dari tujuan dan identifikasi konsumennya. Karena hal tersebutlah, logo, sebagai visual elemen, bukan hanya sebagai bentuk citra dan gambaran, melainkan juga menjadi representatif dan mencerminkan atribut kepada para konsumen dan membangun identitas mereka (Morgan, Pritchard, and Pride, 2011).

Identitas dalam visual yang dihadirkan menjadi hal yang menarik sebagai alat komunikasi. Komunikasi visual telah dipraktikkan selama berabad-abad sejak era pra-sejarah dan digunakan untuk berbagai alasan seperti komersial, pendidikan, dan ekspresi artistik (Young, 2003). Dengan bentuk komunikasi melalui visual hal ini dapat memperlihatkan bagaimana representasi milenial itu terbangun dan terbentuk? Bahkan secara tidak langsung, identitas memberikan peranan seperti apa peranan anak milenial jaman sekarang secara demografisnya.

Dalam penelitian ini, peneliti membuat penggunaan istilah "logo" untuk merujuk elemen grafis yang digunakan perusahaan minuman "bubble drink" untuk mengidentifikasi produk dan budaya masyarakat itu sendiri. Dengan demikian, penelitian ini mengasumsikan bahwa logo dapat mengidentifikasi gaya, bentuk, serta budaya masyarakat sekitar yang memang memberikan minat terhadap produk yang ada. 


\section{METODE PENELITIAN}

Penelitian ini menggunakan paradigma konstruktivisme. Kerangka penafsiran konstruktivis dideskripsikan sebagai intepretivisme, yakni melihat dan memahami individu-individu berusaha memahami dunia tempat mereka hidup dan bekerja. Teknik Analisis dan Penyajian data dalam penelitian kualitatif dimulai dengan menyiapkan dan mengorganisasi data, yang kemudian mereduksi data tersebut menjadi tema melalui proses pengodean dan peringkasan kode. Selanjutnya, menyajikan data dalam bentuk bagan, tabel, atau pembahasan (Creswell, 2014).

Metode dalam penelitian ini menggunakan metode analisis wacana sebagai usaha untuk mengungkap makna teks yang hadir dalam masyarakat (Einsenhart dan Johnstone, 2008). Analisis wacana tidak untuk kita berargumetasi melawan validitas dan "kebenaran" dari metode penelitian tertentu, melainkan berfokus kepada keberadaan dan pesan atau isi dari teks didalam konteks sosial (Ida, 2014). Dengan analisis tekstual, penelitian ini melihat dan membongkar interpretasiinterpretasi yang dihasilkan oleh teks. Dalam penelitian tekstual, interprestasi yang digambarkan tidak selalu harus benar, melainkan harus mampu memberikan kepercayaan atau keyakinan bagi argumenargumen penelitian (McKee, dalam Ida, 2014. Hal: 64-65). Pada konteks analisis teks ini mempunyai arti bahwa 'teks' tidak diartikan secara sempit, melainkan arti yang sangat luas, yaitu segala objek mulai dari literatur, gambar, film, atau praktik-praktik sosial di masyarakat yang mempunyai signifikasi makna menjadi objek kajian dari tekstual.

Sumber data dalam penelitian ini mengambil 17 logo gerai minuman di daerah Tangerang Selatan, yaitu, Auss, Boba Time, Bu Be, Di Sedot, Haus, Hepi Boba, Lakoe, Mama Haus, Manja, Minum In, Munim, Mynum, Phi Phi Island, Teguk, Ya Ya Ya, dan Glek. Setiap logo yang hadir pada ke17 gerai tersebut, elemen-elemen visual dibongkar menggunakan teori elemen visual, metamorph visual yang akan menerangkan elemen-elemen seperti apa saja yang hadir pada setiap logo dalam pengaturan keterlibatan antara elemenelemen visual (Leong, 1993). Dalam penelitian visual, teknik grammar visual, ikon/image, indeks, simbol adalah perangkat analisis wacana (Poynton, 2000, dalam Ida, Hal: 96-97).

Setelah didapati elemen-elemen visual yang telah di bongkar, selanjutnya adalah melihat kesamaan, ciri khas, serta bentuk-bentuk visual yang ada, sehingga tipe dan gaya visual akan didapati (Smith, Moriarty, Barbatis, Kenney; 2005). Dengan demikian, representasi budaya yang dihadirkan pada logo tersebut terjawab.

\section{HASIL DAN PEMBAHASAN}

Dalam 17 logo yang hadir pada gerai minuman boba drink di daerah Tangerang Selatan, elemen visual yang dihadirkan menjadi tiga bentuk yaitu bentuk (shape), tipografi, dan warna. Berikut elemen-elemen yang divisualisasikan pada logo gerai minuman tersebut: 


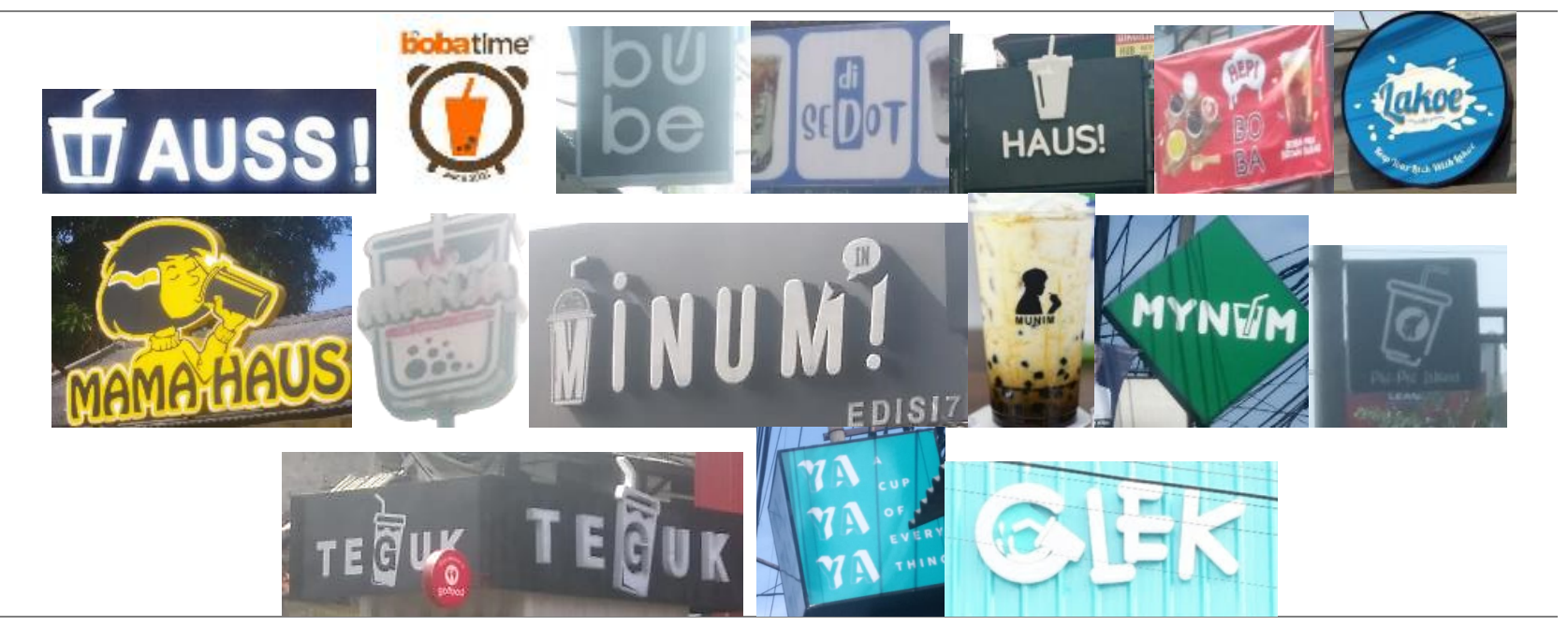

Sumber: logo gerai minuman bubble drink oleh foto pribadi dan internet

Gambar 1. Logo Objek Penelitian

Tabel 1. Elemen visual logo pada gerai boba drink

\begin{tabular}{|c|c|c|c|c|c|c|}
\hline \multirow{3}{*}{$\begin{array}{l}\text { Black and } \\
(C M Y K) \\
\quad \text { Name }\end{array}$} & \multicolumn{2}{|c|}{ White $\quad(B / W)$} & \multicolumn{2}{|c|}{ Red-Green-Blue } & $(R G B)$ & \multirow{2}{*}{$\begin{array}{l}\text { Cyan-Magenta-Yelow-Key } \\
\text { Warna }\end{array}$} \\
\hline & Bentu & (Shape) & & grafi & & \\
\hline & Tipe & kategori & Tipe & kategori & Tipe & kategori \\
\hline Auss!! & Solid & Ikonik: Gelas & Serif & Solid & $\mathrm{B} / \mathrm{W}$ & Contrast \\
\hline Boba Time & Shapes & Ikonik: Jam & Sans Serif & Shapes & RGB & Soft \\
\hline $\mathrm{Bu} \mathrm{Be}$ & Shapes & Semi & Sans Serif & Shapes & $\mathrm{B} / \mathrm{W}$ & Contrast \\
\hline Di Sedot & Shapes & Non ikonik & Dekoratif & Shapes & RGB & Soft \\
\hline Haus! & Solid & Ikonik: Gelas & Sans Serif & Shapes & $\mathrm{B} / \mathrm{W}$ & Contrast \\
\hline Hepi Boba & Solid & Ikonik: Gelas & Sans Serif & Shapes & RGB & Contrast \\
\hline Lakoe & Shapes & Non ikonik & Dekoratif & Shapes & RGB & Soft \\
\hline Mama Haus & Shapes & $\begin{array}{l}\text { Ikonik: } \\
\text { Manita } \\
\text { minum } \\
\text { dengan gelas }\end{array}$ & Sans serif & Shapes & CMYK & Soft \\
\hline Manja & Shapes & Ikonik: Gelas & Sans serif & Shapes & RGB & Contrast \\
\hline Minum In & Shapes & Ikonik, Gelas & Sans serif & Shapes & $\mathrm{B} / \mathrm{W}$ & Contrast \\
\hline Munim & Shapes & $\begin{array}{l}\text { Ikonik: pria } \\
\text { minum }\end{array}$ & Sans serif & Shapes & $\mathrm{B} / \mathrm{W}$ & Contrast \\
\hline Mynum & Shapes & Ikonik: Gelas & Sans serif & Shapes & $\mathrm{B} / \mathrm{W}$ & Contrast \\
\hline Phi Phi Island & Shapes & Ikonik: gajah & Sans serif & Shapes & $\mathrm{B} / \mathrm{W}$ & Contrast \\
\hline Teguk & Shapes & Ikonik: gelas & Serif & Solid & $\mathrm{B} / \mathrm{W}$ & Contrast \\
\hline Ya Ya Ya & Shapes & Non ikonik & Sans serif & Shapes & CMYK & Soft \\
\hline Glek & Shapes & Ikonik: gelas & Dekoratif & Shapes & CMYK & Soft \\
\hline
\end{tabular}




\section{Identitas Nama dan Ikonitas}

Kepribadian merek mengacu pada karakter sifat dan karakter manusia (Aaker 1997). Misalnya, kinerja sifat riang gembira ditandai oleh sifat-sifat seperti manusia seperti "berani," "muda," dan "imajinatif." Penelitian lain yang juga menunjukkan kepribadian merek kegembiraan dapat mempengaruhi berbagai aspek perilaku dan identitas konsumen (Sundar and Noseworthy, 2016).

Rangsangan yang dihadirkan melalui elemen-elemen visual juga dapat sangat mempengaruhi ekuitas merek (Orth dan Malkewitz 2008). Misalnya, warna (Van Tilburg et al. 2015), bentuk, dan pola (Sundar dan Noseworthy 2016) dapat memengaruhi respons konsumen terhadap elemen merek visual yang dihadirkan pada logo. Selain itu, logo didesain dengan bentuk visual yang secara unik mengidentifikasi merek dapat memengaruhi persepsi merek dan memberikan identitas tersendiri (Van der Lans et al. 2009). Contohnya, logo dinamis dapat membuat merek tampak lebih modern, inovatif, dan bentuk yang sesitifitas terhadap konsumennya (Cian, Krishna, and Elder 2014).

Penamaan pada merek dagang mempunyai identitas yang sejenis atau mungkin hampir mirip satu dengan yang lainnya. Dasar penggunaan nama mendekati terhadap bentuk "minuman" atau "meminum". Konsep nama yang dibentuk mengindikasikan bahwa kategori penamaan dibuat dengan gaya penamaan yang unik, tetapi saling mempunyai kemiripan satu dengan yang lainnya. Dengan demikian, gaya penamaan terhadap merek minuman boba memberikan kesan kepada masyarakat sebagai minuman kekinian, gaul, dan berjiwa muda.

Penggunaan nama gerai minuman, didominasi dengan satu kata yang santai, sederhana dan sangat memungkinkan mudah diingat. Hal ini menunjukan bahwa gerai minuman memberikan nama tersebut agar dapat mudah dipahami dan menjadi ikonitas tersendiri. Selain itu pula, hal ini bisa dipahami juga bahwa anak milenial lebih mempunyai kecenderungan untuk menginginkan nama-nama yang sederhana dan tidak membuat kesulitan untuk mengejanya.

Ikonitas pada logo bukan hanya menjadikan nilai yang penting sebagai identitas merek dagang, tetapi juga memberikan representatif terhadap style anak muda milenial. Karakteristik desain mempengaruhi reaksi kognitif dan afektif terhadap logo, sehingga memberikan kemungkinan para produsen (perancang logo) membangun identitas sebelum mempromosikan, atau menjual produknya (Henderson dan Cote, 2004).

Pada tabel, ikonisasi dalam logo cenderung memilih bentuk sederhana. Ikon minum atau tempat minum dituangkan dengan gambar solid, atau dalam bentuk semi solid yaitu, penggabungan antara logo dengan ikon logo. Ikon gelas, alat minum, atau orang yang sedang minum menjadi pilihan utama pada gerai minuman tersebut. Gambar ditampilkan dengan lentur (shapes) dan mudah diingat, sehingga kontak antara 
gambar dengan makna gambar sangat mudah dicerna oleh anak milenial.

Walaupun beberapa logo gerai minuman menampilkan non-ikonitas dan semi ikonitas seperti $\mathrm{Bu} \mathrm{Be}$, Di Sedot, Lakoe, dan Ya Ya Ya, tetapi dekorasi identitas lebih ditekankan pada penaamaan gerai tersebutHal ini dapat diartikan bahwa, kesederhanaan gambar, bentuk, serta tipe menggambarkan kecenderungan masyarakat milenial yang ingin memeroleh identitas yang simpel.

\section{Bentuk Visual yang Imajiner}

Hubungan antara representasi visual dan identitas dalam ruang lingkup media (baik media cetak ataupun public space) dalam hal ini adalah logo, tentu melihat pendekatan-pendekatan yang mencakup estetika visual. Estetika mempunyai peranan penting dalam memainkan dunia representasi melalui elemen-elemen visual yang hadir dalam setiap bentuk image, desain, logo, dan sebagainya.

Estetika visual (visual aesthetic) didefinisikan bagaimana visual berkomunikasi dan mempengaruhi keindahannya kepada yang melihat hingga ia merasakan ke dalam jiwanya (Smith, Moriarty, Barbatis, Kenney; 2005). Estetika dalam pandangan tradisional dianggap sebagai studi dan teori tentang 'kecantikan' dan tanggapan psikologis terhadapnya (Neufeldt \& Guralnik D. E., 1998). Pendekatan teori ini pun berkembang, dan bentuk psikologis terhadap 'kecantikan' tersebut dapat didefinisikan berdasarkan apa yang ditentukan pada bagian yang disepakati bersama tentang 'representasi' secara umum (Dickie, 1971). Estetika bukan tentang 'benda' tetapi sistem hubungan ekologis dan proses yang menciptakan hubunganhubungan antara visual dengan psikologis masyarakat dan membantu interprestasi sang pelaku (produsen) dan konsumennya.

Objek fisik dalam estetika visual mengandung sifat relasional yang dapat diamati antara semua elemen dalam visual yang terlihat seperti garis (shape), bentuk, nilai, warna, dan sebagainya, terkait dengan elemen-elemen lainnya yang terlihat. Penciptaan makna yang disampaikan terlihat melalui bentuk dan membuat pesan adalah tujuan akhir sang pembuatnya. Sifat fisik (objek) yang konkret menjadi sangat penting bagi konsumen dan pembuatnya untuk membantu mereka saling terhubung dan berkomunikasi. Visualisasi pada logo gerai dapat dispesifikasikan sebagai berikut:

Tabel 2. Estetika sebagai makna dalam visual logo

\begin{tabular}{lll}
\hline Auss! & visual & aesthetic \\
\hline Boba Time & $\begin{array}{l}\text { Jam dering, gelas dengan sedotan, } \\
\text { teks boba time }\end{array}$ & $\begin{array}{l}\text { Referensi tempat minum dengan } \\
\text { gaya kata abstraktif }\end{array}$ \\
& $\begin{array}{l}\text { Referensi jam minum, waktu } \\
\text { untuk minum boba dengan gaya } \\
\text { kata gaul }\end{array}$ \\
\hline $\mathrm{Bu} \mathrm{Be}$ & Huruf "U" dengan sedotan & $\begin{array}{l}\text { Makna U sebagai alat minum } \\
\text { dengan gaya kata abstraktif }\end{array}$ \\
\hline Di Sedot & Teks Di Sedot & Makna teks sebagai ajakan \\
\hline Haus! & Gelas dengan sedotan, teks Haus! & Referensi tempat minum dengan \\
\hline
\end{tabular}




\begin{tabular}{|c|c|c|}
\hline & & gaya kata formal \\
\hline Hepi Boba & Teks hepi boba & $\begin{array}{l}\text { Makna teks sebagai perasaan } \\
\text { riang terhadap boba, gaya teks } \\
\text { abstraktif }\end{array}$ \\
\hline Lakoe & $\begin{array}{l}\text { Visual corak, tumpahan, Teks } \\
\text { Lakoe }\end{array}$ & $\begin{array}{l}\text { Makna teks sebagai tempat yang } \\
\text { banyak diminati (laku), gaya teks } \\
\text { abstraktif }\end{array}$ \\
\hline Mama Haus & $\begin{array}{l}\text { Wanita yang sedang minum, teks } \\
\text { mama haus }\end{array}$ & \begin{tabular}{lcc} 
Referensi & tempat & \multicolumn{2}{c}{ minum, } \\
mengajak & minum, gaya teks \\
abstraktif & &
\end{tabular} \\
\hline Manja & $\begin{array}{l}\text { Tempat minum dengan sedotan, } \\
\text { teks manja }\end{array}$ & $\begin{array}{l}\text { Referensi tempat minum, gaya } \\
\text { teks abstraktif }\end{array}$ \\
\hline Minum In & $\begin{array}{l}\text { Gelas dengan sedotan, teks minum' } \\
\text { in }\end{array}$ & $\begin{array}{l}\text { Referensi tempat minum, gaya } \\
\text { teks abstraktif }\end{array}$ \\
\hline Munim & $\begin{array}{l}\text { Siluet seseorang yang sedang } \\
\text { minum, teks munim }\end{array}$ & $\begin{array}{l}\text { Referensi mengajak minum, gaya } \\
\text { teks abstraktif }\end{array}$ \\
\hline Mynum & Gelas dengan sedotan, teks mynum & $\begin{array}{l}\text { Referensi tempat minum, gaya } \\
\text { teks abstraktif }\end{array}$ \\
\hline Phi Phi Island & $\begin{array}{l}\text { Gambar gajah, denganteks phi phi } \\
\text { island }\end{array}$ & $\begin{array}{l}\text { Tempat wisata, identitas } \\
\text { Thailand, gaya teks abstraktif }\end{array}$ \\
\hline Teguk & Gelas dengan sedotan, teks teguk & $\begin{array}{l}\text { Referensi tempat minum, gaya } \\
\text { teks formal }\end{array}$ \\
\hline Ya Ya Ya & Teks Ya Ya Ya & Makna teks yang abstraktif \\
\hline Glek & Gelas dengan sedotan, teks Glek & $\begin{array}{l}\text { Referensi tempat minum, gaya } \\
\text { teks abstraktif }\end{array}$ \\
\hline
\end{tabular}

Visual yang ditampilkan pada logo minuman boba lebih cenderung menunjukan gambar-gambar yang semi abstrak, atau imajiner. Pemahaman terhadap gaya imajiner ini diartikan bahwa gambar identitas pada logo digabungkan dengan bentuk yang lain, sehingga pemaknaan bukan hanya memberikan kepastian, melainkan juga lebih abstraktif.

Klasifikasi desain logo tersebut mencerminkan sejauh mana desain logo menggambarkan benda yang biasa dialami, dari lingkungan alam serta budaya. Istilah tersebut mengacu pada tanda-tanda kiasan, dan dengan demikian membedakan antara alami dan abstrak desain. Kemudian, dalam desain yang alami, dapat membedakan antara desain budaya dan organik (Henderson dan Cote, 1998). Desain logo organik mengacu pada logo yang menggambarkan "benda biologis", yaitu benda dari dunia alami seperti, bunga, buahbuahan, atau wajah. Pada sisi desain logo lain lebih menggambarkan "objek buatan" seperti, rumah, meja, gelas, sedotan, atau simbol budaya lainnya misalnya tanda baca atau gambar bintang, yaitu benda yang tidak memiliki biologis langsung asal, bangunan, furnitur, benda sehari-hari, simbol tertulis. Logo yang menggambarkan karakter, tempat, hewan, buah-buahan atau benda lain yang mudah dikenali, memberikan kesadaran bahwa hal tersebut dipengaruhi oleh gaya masyarakat terhadap budaya yang abstraktif.

Kealamian dan respons afektif terhadap merek dapat dilihat pada bentuk pembentukan logo lebih strategis dengan logo bergambar. Gambar-gambar yang dihadirkan pada gerai minuman di sekitaran 
Tangerang Selatan, menunjukkan bahwa logo sugestif sebagai objek yang dikenali dapat menambah paling banyak nilai untuk merek yang mereka wakili (Schechter, 1993), seperti bagian minuman atau seseorang yang mau minum. Pilihan logo dengan bergambar atau media bentuk tersebut mewakili objek yang memiliki makna yang dikenal lebih luas, dan menjadi tindakan efektif menghasilkan pengakuan oleh para konsumen, sehingga berpengaruh positif daripada logo yang lebih abstrak (Henderson dan Cote, 1998).

Walaupun demikian, logo yang abstrak dan tidak berarti selalu menjadi nilai yang buruk, walaupun abstrak desain lebih sulit untuk ditafsirkan (Seifert, 1992). Temuan ini didukung oleh keutamaan estetika bentuk alami terhadap logo yang dirancangan. Gambar logo alami memberikan fenomena yang benar-benar nyata dan alami di lingkungan kita, dan karena itu logo alami memungkinkan untuk menjadi logo yang paling disukai (Veryzer, 1999) oleh konsumen atau masyarakat milenial yang kekinian.

\section{Huruf dan Kata yang Tipogratif}

Huruf mempunyai peran penting dalam masyarakat terutama ketika berkomunikasi atau menunjukkan ekspresi. Diyakini bahwa masyarakat mendapatkan efek oleh kepentingan tekstual, karena tipografi hadir dan digunakan setiap hari untuk berbagai tujuan dan beragam area atau ruang (Huerta 2010).

Pada tabel 1, Bentuk dan tipe huruf yang digunakan oleh gerai minuman boba cenderung lentur (shapes) dengan tipe sans serif, yaitu tipe huruf bergaya santai dan tidak formal seperti serif. Tipe huruf sans serif dianggap sebagai huruf yang muda, gaul, dan sederhana, walaupun huruf ini bisa jadi dipakai sebagai huruf yang mewah.

Pilihan jenis huruf bisa memanipulasi makna kata yang diterapkan dan membantu konsumen untuk memahami bagaimana tujuan perusahaan berdiri untuk dan ke mana arahnya (Childers dan Jass, 2002). Kecenderungan tipe yang santai juga ditunjukan pada huruf yang tipogratif yaitu huruf yang dibuat, dirancang, dan diolah dengan menggabungkan gambar lain yang saling berhubungan dengan huruf. Sehingga gaya tulisan ini mempunyai nilai baru dalam kata dan huruf yang sudah dipakai.

Tipografi (huruf) yang tipogratif ini menunjukan bahwa, gaya anak milenial lebih cenderung kepada huruf-huruf yang digabungkan atau beririsan dengan gambar, simbol, atau garis-garis tertentu yang dapat dibaca sebagai kata, dan juga menjadi makna terhadap identitas merek minuman tersebut. Dengan kata lain, tipografi bukan sekedar bentuk huruf, tulisan, dan kata, tetapi juga huruf menjadi sebuah gambar yang mempunyai makna tertentu (tipogratif). Sebagai daya tarik estetika dan desain berkembang menjadi komponen penting sebagai jati diri perusahaan (Schmitt dan Simonson, 1997). Identitas visual perusahaan diekspresikan melalui logo perusahaan dan jenis hurufnya yang unik (Henderson, Giese, dan Cote 2004).

Keunikan huruf menjadi model penting sebagai identitas, baik perusahaan maupun konsumennya. Huruf bukan hanya memberikan peran sebagai media baca, 
tetapi juga pemaknaan terhadap budaya yang hadir disekitar kita. Tentunya huruf menjadi penting bagi perusahaan, mereka tidak serta merta menaruh sembarang huruf sebagai identitas, tetapi estetika, kecantikan, ataupun kesesuaian huruf yang dipakai untuk kategori tertentu. Pemahaman inilah menjadi hal yang sangat penting untuk menentukan sejauh mana elemen kata dan bentuk huruf (tipografi) memberikan kekuatan dan gaya identitas terhadap pelanggannya pula, bahkan budaya masyarakat yang ada.

\section{Kontras Sebagai Kekuatan Identitas}

Secara garis besar, elemen dan identifikasi tipe warna mempunyai banyak variatif (Sundar and Noseworthy, 2016), tetapi secara umum warna dibagi menjadi bagian model dasar, atau bagian-bagian utama yang penting seperti warna dasar grafik yaitu red, green, blue (RGB) dan warna dasar cetak cyan, magenta, yellow, key (black) (CMYK), dan tentunya warna sebagai key atau titik kunci sebagai asosiasi warna yaitu black and white $(\mathrm{B} / \mathrm{W})$, walaupun bagian key juga dianggap bukan bagian warna.

Warna yang dihadirkan oleh para gerai minuman cenderung kepada pilhan 2 warna solid yaitu hitam dan putih $(\mathrm{B} / \mathrm{W})$ sampai 3 warna yang kontras (RGB), dan terlebih lagi pilihan warna yang kontras. Pilihan 2 atau 3 warna ini menunjukan bahwa elemen-elemen yang dihadirkan sesederhana mungkin, dan tentunya menjadi ketertarikan mata (eye catching), serta identitas warna itu sebagai gaya kesederhanaan (simplicity).

Walaupun beberapa pilihan warna mempunyai model warna yang lembut (CMYK), tetapi kesederhanaan masih jadi pilihan, yaitu warna lembut dengan tipe 2 warna seperti biru muda dan putih, atau kuning dengan cokelat muda. Hal ini menunjukan bahwa pilihan warna lebih cenderung kepada warna yang memberikan sisi kekuatan identitas, yaitu warna-warna kontras.

Tabel 3. Identitas warna dan subjek logo

\begin{tabular}{|c|c|c|}
\hline \multirow[t]{2}{*}{ Logo } & \multicolumn{2}{|c|}{ Warna } \\
\hline & Identitas & Subjek \\
\hline Auss!! & Hitam, putih & Sedikit, sederhana, tidak ada variant \\
\hline Boba Time & Jingga, putih, cokelat, putih & Kompleks, variant, simetris \\
\hline $\mathrm{Bu} \mathrm{Be}$ & Hitam, putih & Sedikit, sederhana, tidak ada variant \\
\hline Di Sedot & Biru muda, putih & Sedikit, sederhana, tidak ada variant \\
\hline Haus! & Hitam, putih & Sedikit, sederhana, tidak ada variant \\
\hline Hepi Boba & Merah, putih, hitam & Kompleks, variant, tidak simetris \\
\hline Lakoe & Biru, putih & Sedikit, sederhana, tidak ada variant \\
\hline Mama Haus & Kuning, hitam, putih & Abstraktif, kompleks, variant \\
\hline Manja & Hitam, putih, merah & Abstraktif, kompleks, variant \\
\hline Minum In & Hitam, putih & Sedikit, sederhana, tidak ada variant \\
\hline Munim & Hitam, putih & Sedikit, sederhana, tidak ada variant \\
\hline Mynum & Hijau, putih & Sedikit, sederhana, tidak ada variant \\
\hline $\begin{array}{ll}\text { Phi } & \text { Phi } \\
\text { Island } & \\
\end{array}$ & Hitam, putih & Sedikit, sederhana, tidak ada variant \\
\hline Teguk & Hitam, putih & Sedikit, sederhana, tidak ada variant \\
\hline Ya Ya Ya & Biru muda, putih & Sedikit, sederhana, tidak ada variant \\
\hline
\end{tabular}


Glek Biru, putih

Jika melihat kategori warna yang dihadirkan, kontras menjadi pemain penting sebagai bentuk identitas anak milenial. Warna-warna halus seperti biru muda, merah muda, atau kuning justeru tidak terlalu dominan pada kasus ini. Hal ini memungkinkan bahwa warna halus dianggap sebagai warna feminim yang mengkategorikan sebagai identitas untuk perempuan. Pilihan warna hitam dan putih seperti yang tetertera dalam tabel, merujuk sebagai gerai minuman yang bukan hanya untuk perempuan saja, tetapi untuk para pria. Warna hitam memberikan bermacam corak, ia bisa memberikan makna sebagai ketakutan, keberanian, dan sebagai identitas luxury atau kemewahan. Dengan warna tersebut, pemaknaan terhadap kemewahan yang didapat dengan harga yang murah meriah menjadi nilai pokok yang menjanjikan kepada masyarakat milenianl, khususnya di wilayah Tangerang Selatan.

Pemilihan bentuk kontras dalam pewarnaan logo juga menjadi hal yang sangat penting sebagai identitas. Dengan warna yang kontras, bukan hanya memberikan kemudahan dalam membaca, selain itu pula mendefinisikan bagaimana kenikmatan dalam melihat bentuk objek warna oleh masyarakat itu sendiri. Variasi warna yang diadopsi sebagian besar gerai ini hanya menggunakan 2 warna yang sederhana dan menghindari atau mungkin menolak variant (macam-macam) warna yang kompleks. Warna hitam dan putih mendominasi dari berbagai pilihan warna ditimbang dengan warna lainnya. Sehingga,
Sedikit, sederhana, variant

dengan melihat pilihan warna yang ada, bisa diasumsikan bahwa anak milenial secara gender mempunyai kecenderungan memilih dan menikmati warna kontras.

\section{SIMPULAN}

Penelitian ini menyimpulkan bahwa identitas nama dan visual tersebut memberikan bentuk genre anak milenial jaman sekarang. Pertama, penamaan sebagai identitas didominasi dengan bentuk nama yang sederhana pula, yang mungkin mempunyai makna yang tidak sulit dipahami. Nama-nama simpel yang mempunyai satu kata yang mudah diingat. Warna yang kontras dalam identitas visual menunjukan bahwa, kecerahan menjadi modal utama sebagai penarik (eyecatching) dan identitas anak milenial. Ketiga, tipografi yang ditampilkan lebih cenderung tipogratif, secara afektif, penggunakan tipografi ini menunjukan tingkat 'simplicity' yang mudah dipahami.

Implikasi pada penggunaan elemen visual pada ke 17 gerai minuman bubble tea di Tangerang Selatan selain menampilkan kesederhanaan dalam identitas visual, juga secara tidak langsung membangun identitas masyarakat milenial di daerah tersebut. Hal ini ditemukan bahwa identitas pada masyarakat kekinian lebih cenderung menerima kesederhanaan (tidak kompleks dan mewah), yang dapat merangkul ke semua masyarakat baik pria maupun wanita.

Beberapa temuan penelitian ini dapat dijadikan dasar untuk mengembangkan ilmu komunikasi, khususnya komunikasi visual 
tentang identitas visual yaitu logo. Selain itu juga dengan penelitian ini diharapkan memberikan masukan kepada pengembangan komunikasi visual baik secara teoretis maupun praktis. Walaupun demikian, temuan peneliti dapat digunakan sebagai titik awal untuk masa depan penelitian. Hal tersbut dikarenakan beberapa topik yang belum dijelajahi pada penelitian ini, seperti kompleksitas visual dan angularitas.

\section{UCAPAN TERIMA KASIH}

Peneliti mengucapkan terima kasih kepada teman dan kolega yang memberikan arahan, masukan, serta referensi terhadap penelitian ini. Tidak lupa juga ucapan terima kasih kepada pengelola dan reviewer jurnal penelitian ini yang juga memberikan tanggapan yang positif dan membangun kepada peneliti, sehingga memberikan semangat dan motivasi dalam penelitian selanjutnya.

\section{DAFTAR PUSTAKA}

Aaker, D. (2007). Managing the lost important asset: Brand equity. Planning Review, Hal: 56-58.

Aaker, Jennifer L. (1997), "Dimensions of Brand Personality," Journal of Marketing Research.

American Marketing Association (2018). Dictionary of the American marketing association. Diakses 10 Maret 2020. https://www.ama.org/resources/Pages/ Dictionary.aspx?dLetter $=$ B.

Ashworth, G., \& Kavaratzis, M. (2009). Beyond the logo: Brand management for cities. Journal of Brand Management.

Black, Iain., Veloutsou, Cleopatra (2016) Working consumers: Co-creation of brand identity, consumer identity and brand community identity. Journal of Business Research.

Chang, D. (2017). Bubble tea: How did it start? Available: https://edition.cnn.com/travel/article/bubble-tea-inventor/index.html. Diakses: 10 Maret 2020.

Chaudury, A. and Holbrook, M.B. (2001), "The Chain of effects from brand trust and brand affect to brand performance: the role of brand loyalty", Journal of Marketing, Vol. 65 No. 2, Hal: 81-93

Childers, T. L., and J. Jass. (2002). "All Dressed Up with Something to Say: Effects of Typeface Semantic Associations on Brand Perception and Consumer Memory." Journal of Consumer Psychology, Hal:93-106.

Cian, Luca, Aradhna Krishna, and Ryan S. Elder (2015), "A Sign of Things to Come: Behavioral Change Through Dynamic Iconography," Journal of Consumer Research.

Creswell. W. John. (2014). "Penelitian Kualitatif \& Desain Riset: Memilih di Antara Lima Pendekatan". Edisi Bahasa Indonesia 2014. Yogyakarta. Pustaka Pelajar.

De Chernatony, L., \& Dall'Olmo Riley, F. (1998). Modelling the components of the brand. European Journal of Marketing. 
Dickie, G. (1971). Aesthetics: An introduction. New York, Pegasus Books.

Eisenhart, C. dan Johnstone, B (Eds.). (2008). Discourse Analysis and Rethorical Studies. Philadelphia. Benjamins Publishing Company.

Frojdo, H. Mei. (2018). Feasibility Of A Bubble Tea Shop In Jakobstadmarket Acceptance Of Bubble Tea. Thesis Centria University Of Applied Sciences Business Management.

Henderson, P.W. and Cote, J.A. (1998), "Guidelines for selecting and modifying logos", Journal of Marketing, Vol. 62 No. 2, Hal: 14-30

Henderson, P.W., Giese, J.L. and Cote, J.A. (2004), "Impression management using typeface design", Journal of marketing, Vol. 68 No. 4, Hal: 60-72.

Homburg, C., Schwemmle, M., \& Kuehnl, C. (2015). New product design: Concept, measurement, and consequences. Journal of Marketing, 79(3), 41-56.

Huerta, R. (2010). I like cities; Do you like letters? Introducing urban typography in art education. JADE 29.1 (2010) The Author, Journal Compilation. Hal: 72-81.

Ida, Rachmah. (2014). Metode Penelitian Studi Media dan Kajian Budaya. Jakarta. Prenadamedia Group.

Jenkins, O. (2003). Photography and travel brochures: The circle of representation. Tourism Geographies, Hal: 305-328.

Keller, K. L. (2003). Strategic brand management: Building, measuring, and managing brand equity (2nd ed.). Upper Saddle River, NJ: Pearson.

Kotler, P., \& Keller, K. L. (2016). A framework for marketing management (6th ed.). London: Pearson.

Lutz, K.A. and Lutz, R.J. (1977), "Effects of interactive imagery on learning: application to advertising", Journal of Applied Psychology, Vol. 62 No. 4, Hal: 493-498.

MacInnis, D.J., Shapiro, S. and Mani, G. (1999), "Enhancing brand awareness through brand symbols", Advances in Consumer Research, Vol. 26 No. 1, Hal: 601-608.

Morgan, N., Pritchard, A., \& Pride, R. (2011). Tourism places, brands, and reputation management. In N. Morgan, A. Pritchard, \& R. Pride (Eds.). Destination brands: Managing place reputation. Oxford: ButterworthHeinemann.

Orth, Ulrich R., and Keven Malkewitz (2008), "Holistic Package Design and Consumer Brand Impressions," Journal of Marketing, Hal: 64-81.

Pham, M. T. and Avnet, T. (2004), "Ideals and oughts and the reliance on affect versus substance in persuasion", Journal of Consumer Research, Vol. 30 No. 4, Hal: 503-518.

Pittard, N., Ewing, M., \& Jevons, C. (2007). Aesthetic theory and logo design: Examiningconsumer response to proportion across cultures. International Marketing Review, Hal: 457-473.

Schechter, A.H. (1993), "Measuring the value of corporate and brand logos", 
Design Management Journal, Vol. 4 No. 1, Hal: 33-39.

Schmitt, B.H. and Simonson, A. (1997), Marketing Aesthetics, The Free Press, New York, NY.

Sinclair-Maragh, G. (2018). Destination brand potency. A proposition framework. In D. Gursoy, \& C. G. Chi (Eds.). The Routledge handbook of destination marketing, Abingdon. Routledge.

Smith, Moriarty, Barbatis, Kenney; (2005), Handbook Of Visual Communication: Theory, Methods, And Media; Lawrence Erlbaum Associates, Publishers Mahwah, New Jersey London.

Sundar, Aparna, and Theodore J. Noseworthy (2014), "Place the Logo High or Low? Using Conceptual Metaphors of Power in Packaging Design," Journal of Marketing, 78 (5), 138-51. (2016), “Too Exciting to Fail, Too Sincere to Succeed: The Effects of Brand Personality on Sensory Disconfirmation," Journal of Consumer Research, Hal: 44-67.

Van der Lans, Ralf, Joseph A. Cote, Catherine A. Cole, Siew Meng Leong, Ale Smidts, and Pamela W. Henderson, et al. (2009), "CrossNational Logo Evaluation Analysis: An Individual-Level Approach," Marketing Science, Hal: 968-85.

Van der Lans, R., Cote, J.A., Cole, C.A., Leong, S.M., Schmidts, A., Henderson, P.W., Bluemelhuber, Ch., Bottomley, P.A., Doyle, J.R., Fedorikhin, A., Moorthy, J.,
Ramaseshan, B. and Schmitt, B.H. (2009), "Cross-national logo evaluation analysis: an individual-level approach, Marketing Science, Vol. 28 No. 5, Hal: 968-985.

Van Tilburg, M., Theo Lieven, Andreas Herrmann, and Claudia Townsend (2015), "Beyond Pink It and Shrink It: Perceived Product Gender, Aesthetics, and Product Evaluation," Psychology \& Marketing, Hal: 422-437.

Veryzer, R. W. (1993). "Aesthetic Response and the Influence of Design Principles on Product Preferences." Advances in Consumer Research.

Young, R. E. (2003). Adult education principles and philosophies for undergraduate visual communication design education. Antigonish, Nova Scotia: St. Francis Xavier University. 